\title{
Loretto Academy Niagara (1861-1969): Education Under the Rainbow ${ }^{1}$
}

\author{
Elizabeth Smyth \\ Ontario Institute for Studies in Education, University of Toronto
}

\begin{abstract}
This essay explores the origins of, and elements of teaching and learning at Loretto Niagara, a girls' boarding and day school operated by the Irish-based Institute of the Blessed Virgin Mary (The Loretto Sisters). Three key individuals shaped the development of Loretto Niagara: Michael Power, the first Roman Catholic Bishop of Toronto, Archbishop John Joseph Lynch, his second successor and Mother Teresa Dease, one of Loretto's Canadian pioneers. Power was the bishop who invited the community to Canada; Lynch imagined a Catholic educational presence on the shores of the Falls and Dease contributed to the actualization of that vision. Through an analysis of archival sources, the paper argues that in the course of its 100 plus year existence, Loretto Niagara's physical location gave shape to its overt and hidden curriculum. Its history documents the complexities of the intersection of gender and religion in the education of young women.
\end{abstract}

Key words: Women religious; girls' education.

RESUMEN

Este ensayo explora los orígenes y los elementos de la enseñanza y el aprendizaje en el Insituto de niñas Loretto Niagara, que estaba regido, en régimen de internado y externado, por el Instituto, de origen irlandes, de la Bendita Virgen María (las Hermanas de Loretto). Tres individuos fundamentales contribuyeron al desarrollo del Instituto Loretto Niagara: Michael Power, el primer obispo católico de Toronto, el arzobispo John Joseph Lynch, su segundo sucesor, y la Madre Teresa Dease, una de las pioneras canadienses de Loretto. Power era el obispo que invitó a la comunidad a Canadá; Lynch imaginó una presencia educativa católica en las orillas de las Cataratas; y Dease contribuyó a la realización de esa visión. Con un análisis de fuentes archivisticas, el artículo argumenta que en el curso de sus más de 100 años de existencia, la localización física del Instituto Loretto Niagara dió forma a su curriculum tanto explícito como oculto. Su historia documenta las complejidades de la intersección del género y la religión en la educación de las jóvenes.

Descriptores: Religiosas, Educación de las niñas

RÉSUMÉ

Cet essai explore les origines de l'enseignement à Loretto Niagara ainsi que les éléments de l'enseignement et de l'apprentissage à cette école pensionnat et externat pour filles dirigée par l'Institut de la Bienheureuse Vierge Marie (les Sœurs de Loretto) dont le centre est en Irlande. Trois individus clés ont déterminé le développement de Loretto Niagara: Michael Power, le 
premier évêque catholique romain de Toronto, l'archevêque John Joseph Lynch, son deuxième successeur et Mère Teresa Dease, une des pionières canadiennes de Loretto. Power était l'évêque qui a invité la communauté au Canada; Lynch a imaginé une présence éducative catholique sur les rives des Chutes; et Dease a contribué à l'actualisation de cette vision. A travers une analyse des sources archiviques, le papier affirme qu'au cours de ses quelque cent ans d'existence, la situation physique de Loretto Niagara a influencé son programme d'études tant officiel qu'officieux. Son histoire documente les complexités de l'intersection du sexe féminin et de la religion dans l'éducation des jeunes filles.

Mots-clés: les religieuses, l'éducation des filles.

So crowned with peace this cloistered abbey seems

And on its peerless heights serene doth rise

While deep below the raging floods are hurled. ${ }^{2}$

W

1th these words, an early twentieth century Canadian poet described the iconic convent girls' school located on a peak overlooking Niagara Falls. For over 100 years, Loretto Niagara, the convent academy of the Institute of the Blessed Virgin Mary, educated generations of children and young women as one in an international network of Loretto convent schools, that followed in an educational tradition established by the order's founder, the revolutionary Elizabethan English educator, Mary Ward. The school drew "young lady pupils," ages 5 through 18, from across Englishspeaking Canada and around the world as day and boarding pupils. For a brief part of its history, Loretto Niagara also educated a very few young boys - but only as day pupils - in Grades 1, 2 and 3. ${ }^{3}$

The spray arising from Niagara Falls generated a famous rainbow that would lend its name to the school's literary magazine. The Niagara Rainbow was established in 1893 by Mother Filomena Clancy and with six of her pupils. Four issues were published a year. By 1906, the name was changed to Loretto Rainbow and its focus broadened to serve all the schools in the North American Loretto network. Richly illustrated with photographs and drawings, The Rainbow documented not only all those international visitors who called at the school, informed alumnae of the progress of their members, displayed the poetry and prose of the students but also served a marketing vehicle for the schools. At its height, its circulation reached $4000 .{ }^{4}$ Among its multiple purpose were the facilitation of communication among parents and current pupils, past pupils and their Loretto teachers, and the larger community of which the school was a part.

The rainbow was also the symbol of the Loretto Alumnae Association, formed in 1910 in preparation for the school's $60^{\text {th }}$ anniversary. Like many other such associations, its aims were social, spiritual and intellectual - as well as fundraising. The Alumnae Association was part of the International Federation of Convent Alumnae. This association still exists in 2006 - annually holding events including a memorial celebration of former pupils.

The Rainbow is but one of a variety of sources held within the Archives of the Insitute of the Blessed Virgin Mary (Canadian Province) and other public and private archives that document life and learning at Loretto Niagara. Through an analysis of 
these sources, the paper argues that in the course of its 100 plus year existence, Loretto Niagara's physical location gave shape to its overt and hidden curriculum. Its history documents the complexities of the intersection of gender and religion in the education of young women.

\section{Convent Educators: Vowed Women}

The history of convent education in Canada is in fact the history of the involvement of women religious with education. With the arrival of the Order of St Ursula (the Ursulines) in Quebec in 1639, European women religious became an important part of the Canadian educational experience. ${ }^{5}$ Between 1639 and 1939, 103 orders of women religious operated 2345 or $76 \%$ of the 3100 Catholic educational institutions in Canada, with over $60 \%$ of these orders being of European origin. ${ }^{6}$ Women religious taught in a variety of types of schools: diocesan separate elementary schools; upper schools called Select Schools; in nursing schools; teacher education institutions; degree granting universities and the private schools for young women housed in the order's mother-house.

Women religious represent doubly marginalized cohort of educators whose contributions have yet to be explored, especially by secular scholars in English Canada. ${ }^{7}$ There are many factors that contribute to this gap in the historical record. Not only are the members of this cohort women, but they are women living under vowed norms within a religious patriarchy. Some of their own practices have contributed to this marginalization. First, their historical identity of silent serving led some communities to view the vow of obedience as embodying humility and thus they did not campaign for public recognition for their achievements. In the words of the maxims of the Sisters of St Joseph, (phrases which were learned by every novice as part of her religious formation):

Desire neither praise nor reward for your good works in this life ... On the contrary behave in such a manner that your good actions are hidden in time and known to God alone to appear only in eternity and even never to appear, if God so wills."

Yet, in the words of Carolyn Heilburn, some of these same women who heard and lived these lines, "finding no satisfactory place for themselves in the world, learned to call upon other talents and other attributes, choosing threshold over societal confirmation." "

Second, learning how these talents were utilized is in fact no easy task since the archival sources through which scholars could analyze their significance are housed in private, and until relatively recently, strictly controlled domains. It has only been with the renewal of religious life stimulated by the Second Vatican Council, that women religious, both themselves and collaboratively with secular historians, have begun to analyze their historic and historical roles. ${ }^{10}$ 
Third, for some feminist historians, the fact that women religious exist within the patriarchal Roman Catholic Church, assigned to roles which were separate and unequal to that of vowed men led some to dismiss the work of these women as servants of that institution. ${ }^{11}$ This latter fact is exacerbated by the practice of bishops and clergy recruiting communities of women religious to work in education, often working under challenging conditions. The history of the community that established Loretto Niagara well fits this latter descriptor.

\section{The Roots of Loretto Niagara}

Three key individuals shaped the development of Loretto Niagara: Michael Power, the first Roman Catholic Bishop of Toronto, Archbishop John Joseph Lynch, his second successor and Mother Teresa Dease, one of Loretto's Canadian pioneers. Power was the bishop who invited the community to Canada; Lynch imagined a Catholic educational presence on the shores of the Falls and Dease contributed to the actualization of that vision. ${ }^{12}$

In order to provide Catholic education for the children of his newly created diocese, Michael Power invited a number of European religious communities to establish foundations. ${ }^{13}$ Mother Teresa Ball, the superior of the Loreto Convent in Rathfarnham, Ireland, accepted the invitation. Toronto was the fourth international mission established by her community. Following foundations in Calcutta (1841), Mauritius (1844), and Gibraltar (1845), five sisters came to Toronto in 1847 to establish an elite girls' school and Toronto's first common Catholic schools. The Sisters opened their elite school to nine pupils on 29 September 1847, thirteen days after their arrival. The number of pupils is reflective of the conditions into which they arrived. A typhus epidemic was raging and the sisters who came to teach (and indeed were members of an order dedicated to education) found themselves nursing the dying in extremely primitive conditions. On October 1, the epidemic claimed Bishop Michael Power. Their own small band would suffer from disease and the extremes of the Canadian climate to the point where the mission was "on the brink of failure." ${ }^{14}$ Archbishop Armand de Charbonnel, Power's successor wrote:

These good ladies have suffered more than I can say. Deprived of a bishop, of a house, and of many things during three years, I am amazed at their having got through the numberless difficulties the contend with ... There is a good spirit in the house, they are esteemed and cherished by their pupils and all who are acquainted with them; they have done and will do much good among the Catholics and protestants ... Still the members of the house are few; the Reverend Mother is very delicate; Sister Gertrude keeps to her bed [she had had a foot amputated because of frost bite], one has died; in fact they are overwhelmed ... they have suffered heroically; they are sinking under the hardships of their situation. ${ }^{15}$

The Sisters had no choice: in the spring of 1851, they had to temporarily close their boarding school. Yet, soon after, the community's fortunes began to change. The enroll- 
ment of Canadian women and the arrival of additional Irish sisters established a firmer footing for the community, enabling them to resume and to expand their network of convent schools. Some had brief existences (Brantford 1853-1859; London 1855-56; Belleville 1857-1865- 1876-1889) and others lengthy ones : (Guelph (1856-1966; Hamilton 1865-1970; Stratford 1878-1973; Joliette 1880-1919; Englewood (Chicago) 1892-1962; Woodlawn (Chicago) 1905-1972; Sacramento 1955-present; Sault St Marie 1896-1985; Lindsay 1874-1980 Niagara (1861-1969). ${ }^{16}$ While each school followed the prescribed curriculums of the local secular authorities and followed the Loretto principles of education, each developed its unique local character. In the case of Loretto Niagara, the environment played a key role in shaping the character of the school.

Niagara Falls has always held a significant place in the lives of the peoples who lived on its banks and the visitors who came to view this wonder of the world. From the legend of the Maid of the Mist (with competing and anthropologically contested versions - all dealing with a young woman who was either a human sacrifice or attempting to commit suicide ${ }^{17}$ ) to Oscar Wilde's assessment after his visit in 1882:

The Niagara Falls is simply a vast amount of water going the wrong way over some unnecessary rocks; the sight of that waterfall must be one of the earliest and keenest disappointments in American married life. ${ }^{18}$

Niagara Falls lives as a dominant image in popular culture. To Irish born Archbishop JJ Lynch, it was a powerful symbol of God in Nature. In an 1876 Pastoral Letter, he explained that the vision of Niagara has "haunted" him throughout his life: "The place has been to us from childhood an object of the greatest interest. A picture of it fell into our hands - we were awe-struck with its beauty and wished that we could adore God there. The vision of it haunted us through life." ${ }^{19}$ The Falls were:

nature's high altar. The water, as it descends is in white foam, the altar cloth; the spray, the incense the rainbow the lights on the altar. One must cry out: 'Great is the Lord and admirable are his works. How great is thy name throughout the whole work. Let us adore and love him with our whole hearts and our souls. ${ }^{20}$

Lynch observed: "The Cataract of Niagara yearly attracts thousands of lovers of sublimity and grandeur. They come to wonder but few, alas to pray" ${ }^{21}$ and so,

On our being appointed by the Holy See Bishop of Toronto, it was our first care to secure on the Canada side of Niagara Falls a large tract of land on which to erect religious establishments, where God would be worshipped with a perfect homage of sacrifice and praise and where the Catholic Church would be fittingly represented. It was the commencement of the American civil war [1861]. Our heart was moved with sorrow at the loss of many lives ... The beautiful rainbow that spanned the Cataract, the sign of peace between God and the sinner suggested prayers and hopes to see the war ended. ${ }^{22}$ 
Lynch worked to have three religious sites established on the land he purchased: a small chapel that was designated as shrine to Our Lady of Peace; the Monastery of the Fathers of Our Lady of Mount Carmel and a Convent of the Loretto Sisters. Lynch foresaw the convent as a place of learning and of prayer - where the teaching sisters

whilst not engaged in imparting a higher education to young ladies who assemble at the Convent from all parts of the world, occupy their time in adoring God and contemplating his sweetness and bounty in the Blessed Sacrament ... prayer arise to heaven as the spray ascends to form the clouds that fertilize the earth with refreshing showers. ${ }^{23}$

Lynch approached Mother Dease to establish a school and she accepted - with conditions:

We consented to do supposing that the house in which the nuns were to make a beginning would not cost more than four hundred dollars to repair; but it was an old tavern or inn in which many repairs were needed and it would be impossible to describe the roil and expense that the said house entailed on the poor nuns chosen for the foundation. ${ }^{24}$

And toil the community did. Loretto Niagara was opened on 6 June 1861 in the former Canada Inn by Mother Joachim Murray, Superior, and six sisters whose numbers included Choir and Lay Sisters. ${ }^{25}$ The Choir sisters were classroom and music teachers; the lay Sisters maintained the convent school. The Register of 1861 notes nine boarders, ranging in age from 8 to 23, who were residents of both the United States and Canada. The occupations of their parents were primarily entrepreneurial (hotel keepers, shop keepers, hardware merchant) or military/civil service. Together the professions, these parental occupational classes were constant throughout the school's history.

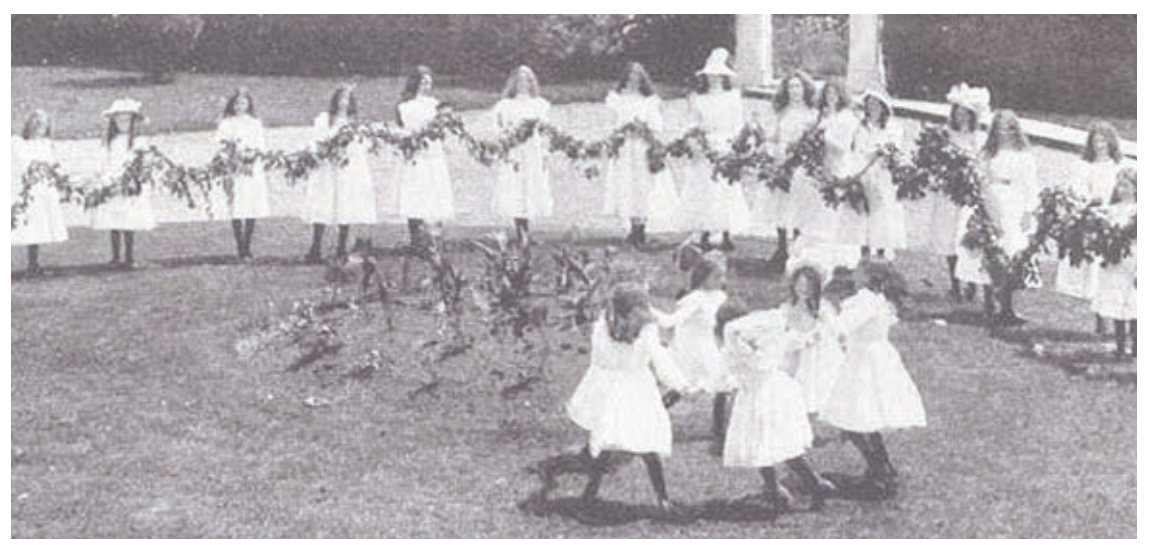

Loretto Niagara. Reproduced with the permission of the Institute of the Blessed Virgin Mary, Canadian Province Archives. 
By 1871, the school was operating in a purpose built structure that housed a school, boarding areas, convent, chapel and landscaped grounds. Success of the school necessitated expansions in 1890 and 1925 and an almost complete rebuilding after a disastrous fire in 1938. The building housed the members of the Loretto community who taught in the provincial separate schools of the Niagara peninsula and served as a place of retreat and recreation for the community who traveled from Toronto to enjoy the scenic beauty of the site.

\section{Life and Learning at Loretto Niagara}

For the nineteenth century parents, regardless of their religious affiliation, convent education for their daughters held great cache. ${ }^{26}$ As a Toronto reporter observed:

It is almost unnecessary to speak of the great and priceless advantages which a convent education confers and which are never mentioned in the prospectus: the grace and propriety of deportment, the many small accomplishments, the thought and consideration for others, and the early training in obedience and modesty, ... at less than the price demanded for a more worldly and often useless education in a non-Catholic College. ${ }^{27}$

Part of this success can be traced to the fact that the schools were administered by women who saw teaching not only as a job but as a vocation. Loretto Niagara was under the "Direction of the Ladies of Loretto" a community whose members were exclusively dedicated to education. In the words of their constitution:

The Institute of the Blessed Virgin Mary (The English Virgins) is a religious congregation.. Its end is the salvation and perfection of all those who ... have therein consecrated themselves to their Lord and Creator ... their special vocation requires them to labour, zealously for the salvation of their neighbour chiefly by the education and training of girls in the principles of a truly Christian life. ${ }^{28}$

Teaching Sisters are to act as models to their pupils, using our most Blessed Mother ... is to be their model and their guide in educating girls. Their vocation is not merely to form the minds of their pupils by secular learning but much more to inspire them with lofty ideals and a love of all goodness. Their own lives, in consequence, should exemplify what they teach so that their pupils may see the gentleness and strength of a true Christian character and many come to realize that holiness is the most important thing in life, in which alone, amid the vicissitudes of the future they can find true happiness. ${ }^{29}$

The school's brochures and application forms offer a glimpse into the hidden and overt curriculum. Loretto was an academy for the education of young ladies, where a successful pupil was not solely defined in terms of academics for "However successful a pupil may be in her studies, she cannot receive the honors of the Academy unless her conduct is that of a true and Christian lady. ${ }^{30}$ Simplicity of dress was stressed. The 
uniform "consists of a black dress, not silk or satin ... no colored dresses or trimmings allowed... One white dress is required for concert purposes." In addition to the "English and Modern Languages" that was part of the regular fees; pupils were offered lessons in piano, harp, stenography, class singing, painting in water colors, oil painting, and china painting by members of the community. Guitar, violin, vocal music and elocution were available "at Professor's charge" - indicating that an individual from outside the congregation would provide these classes. ${ }^{31}$

Loretto Niagara's physical location is the key to its identity. Loretto Beautiful, a brochure for the school [circa 1900], stressed location, location, location. The school's 'high and healthy' locale offered unique opportunities for the resident pupils. The cover is composed of images of art and nature: the falls and the maple leaves are foregrounded; the text is the words to one of the many poetic and literary works generated by or about the school:

Beside Niagara’s sounding deeps,

Dark wooded isles and vine-clad steeps

Like incense rise the clouds of spray;

Where rainbows shone at close of day,

Thy children all with hearts aflame,

Sing to thy gracious, holy name,

Ave Maria Loretto. ${ }^{32}$

This piece is especially significant. It is the school song written in 1894 by two men closely associated with the Congregation of the Mission (the Vincentians) administered Niagara University in Lewiston New York: Thomas Vincent Welch, a member of the Board of Trustees wrote the words and Dr J. Ernest Rieger, the long serving Director of Music, wrote the music. ${ }^{33}$

The Sisters stated their goals for the school:

The Ladies who conduct the establishment consider themselves conscientiously bound to respond to the confidence parents or guardians place in them by giving their pupils a Christian and virtuous education, strictly attending to their intellectual improvement, cultivating the refinement of manners, which will fit them for society and giving them that physical care which they would receive under the parental roof..$^{34}$

Photographs and accompanying captions document opportunities for academics, the arts, and sport and leisure studies as well as for spiritual development. ${ }^{35}$ Yet, while the "Rosary walk" is highlighted, the note beside the photograph of the chapel alerts the reader to the religious diversity of the student body "Difference of religion forms no obstacle to the admission of pupils, provided they are willing to conform to the general regulations of the school." Harkening again to the role of physical activity, the brochure relates: 
It is now a well-recognized principle of modern education that physical development is just as important as mental development. To provide for the physical welfare of the pupils, the Academy has made ample provision for recreation and sports and each pupil is required to reasonably participate in outdoor games. ${ }^{36}$

- games that included archery, basketball, badminton, riding, swimming (after 1925 in the Academy's indoor swimming pool), skating, and tobogganing.

The school appealed to both American and English-speaking Canadian parents. The brochure notes that "All trains from New York, Chicago and Buffalo stop at Falls View. A local trolley terminating at the Convent, connects with the Great Gorge Route, International R.Co., Grand Trunk and Michigan Central RR" and that the curriculum satisfied both Canadian (Ontario) and American (Regents of the State University of New York) requirements. ${ }^{37}$ Throughout the history of the school, American girls and young women attended Loretto Niagara as boarders. While the American student population was never the majority, their constant presence did influence the culture of the school, with American holidays being celebrated and American public affairs both taught and discussed.

The images in the pages that follow document the activities in which the young women engaged - in the classroom, the chapel, the playing field and the concert hall. Choral and instrumental music, painting, drawing, recitations and musical performances, sometimes held out of doors, sometimes at the Carmelite auditorium in the adjacent school, were staged for visiting dignitaries - both religious and secular. The skills displayed in this specialized space equipped the young women who participated in them with the pose, self-confidence and discipline to go on and make public presentations in the wider world. The annual graduation exercise, that took place at the Auditorium of the Carmelite Monastery, was an important public events. It had two purposes: to showcase musical, vocal, dramatic and intellectual achievements of the pupils and secondly, to enable the order to showcase the achievement of the Academy as it applauded the accomplishments of its pupils.

The Application for the 1938 describes the school as offering a "course of training moral, educational and cultural" that has "stood the text of over three-quarters of a century and has made steady advances in keeping with the highest ideals of the times." ${ }^{38}$ The curriculum did change with the times - evidenced by a comparison of the report cards. While an 1887 report card lists the typical accomplishments curriculum ${ }^{39}$ of Drawing, Sewing, Deportment, Order. Music" along with Christian Doctrine, Reading, History, Spelling, Grammar, Geography, Letters, Literature, French, German and Penmanship, ${ }^{40}$ other schools in the network had begun the process of aligning their curriculum for examination by external bodies to credential both their programs and to ensure that their pupils qualified for admission to post secondary institutions. In fact, it was a Loretto school located in Lindsay Ontario that was the first convent school to present its candidates for examination by the secular provincial authorities. Thus, although Loretto Niagara was an independent school, its senior grades were examined inspectors of the Ontario Department of Education. ${ }^{41}$ 
The Academy was therefore able to grant Secondary School Graduation Certificates that enabled their pupils to gain access to "universities, colleges and training schools for teachers and nurses in the United States as well as Canada." 42 Expansions of the school reflected this evolution, including the addition of laboratories for "the teaching of Physics, Chemistry, Biology and Botany ... thoroughly equipped and suited to all requirements." 43

Significantly, too, the arts, academics, sport and leisure studies served to integrate religious practice with social display. There were the public displays that gave opportunities to highlight the accomplishments of the pupils and the teaching prowess of the staff.

The rhythms of the days and the year for the young lady pupils closely paralleled that of their teaching Sisters - especially for the boarders. A 1920 boarder's daily timetable consisted of:

$\begin{array}{ll}\text { 6:30 am } & \text { Wake up bell } \\ \text { 6:45 } & \text { Chapel Service } \\ \text { 7:15-7:45 } & \text { Breakfast } \\ \text { 7:45-7:55 } & \text { Room Cleaning } \\ \text { 7:55-8:50 } & \text { Study Hall } \\ \text { 8:50-11:45 } & \text { Classes } \\ \text { 11:15-noon } & \text { Monday/Friday Choral } \\ & \text { Tuesday/Thursday Discussion with mistress } \\ & \text { Wednesday Etiquette } \\ \text { 12:00-12:30 } & \text { Lunch } \\ \text { 12:30-12:55 } & \text { Sewing } \\ \text { 1:00-3:00 } & \text { Classes } \\ \text { 3:00-5:00 } & \text { Monday-Thursday Recreation Room Activities - outdoors } \\ & \text { Walk, swing, baseball - weather permitted } \\ \text { 4:00-5:30 } & \text { Friday - Basketball - Fallsview Public School Gym } \\ \text { 5:00-6:00 } & \text { Study Hall } \\ \text { 6:00-6:30 } & \text { Dinner } \\ \text { 6:30-7:00 } & \text { Recreation Activities } \\ \text { 7:00-8:00 } & \text { Study Hall or Music Practice } \\ \text { 8:00-9:00 } & \text { Study Hall } \\ \text { 9:15 } & \text { Preparation for Bed } \\ \text { 9:30 } & \text { Lights out }\end{array}$

SUNDAY

2:00- 5:00 Walks around Niagara Falls and Campus, accompanied by one of the nuns ${ }^{44}$ 
The order's book of Customs elaborated on the purpose and execution of this timetable. It directs:

As the most important of all studies is that of our holy religion, at least half an hour's instruction on Christian Doctrine should be given a prominent place in the class duties of each day. The annual retreat and the sodalities are also effectual means of promoting virtue and piety among our pupils. The usual sodalities are: the Divine Infant for the Junior School, Holy Angels for the Intermediate School, the Children of Mary for the Senior School. ${ }^{44}$

The Sisters are directed to ensure that discipline is consistent:

At all times, silence should be observed on the corridors and great care should be taken that the pupils walk quietly and in the prescribed order, going from one place to another. On entering or leaving the study hall, refectory etc, they should salute the presiding sister and also salute the nuns when they meet them on the corridors or elsewhere. When a Sister goes to her class, the pupils should rise and salute her, and do the same when she is leaving. ${ }^{45}$

The result of this education would be a pupil who will be of service:

Unless the school develop the gifted minds and the virtuous hear, then neither can society have them at her service. Grace and refinement are usually the results of early and persistent training. As knowledge does not rise spontaneously within ... neither does art become luxuriant without cultivation. ${ }^{47}$

The Sisters identified themselves as servants of the church in attaining this goal:

... Thus the Church, the custodian of truth, has protected learning and sent forth her noblest sons and daughters charges with the embassy of instructing youth. They are accomplishing a grand mission and among these one of the foremost who have contributed their share are the Loretto Nuns at Niagara Falls. $^{48}$

As was typical of many such schools, for part of its history, boarding was a requirement for graduation. Young women in their final year were required to become resident pupils in order to take full advantage of all the academic, athletic cultural and spiritual activities that the school had to offer. One example of the significance of this residential experience can be seen in the aftermath of the fire that almost destroyed the Loretto Niagara complex on 10 January 1938. The graduating class was relocated to Loretto Armour Heights Toronto to complete their year.

From the simplicity of the dress, through the structured elements of the day, to the integration of religious practice in public activities, the Loretto pupils were living a 
culture parallel to that of the Loretto Sisters. They were also sharing in the primary community value of the need for education for women:

Not only do [the Sisters] teach their pupils all that is necessary to make them intelligent and virtuous women but they also teach them the suitable accomplishments and arts, taking care to render them as graceful and polished as is compatible with natural simplicity. ${ }^{49}$

In 1936, the height of the depression, and the school's $75^{\text {th }}$ anniversary, the President of Niagara University challenged the graduands and alumnae to:

Introduce into the lives of others the conviction, the firm and fair conviction that Loretto of Niagara has blessed and enriched your mind, your heart, your soul. These are difficult days for every type of private school. These are especially difficult days for private schools for girls. Parents are more inclined to favor their sons by sending them away to schools and colleges. Many a young lady has suffered in silence disappointment, staying at home while her brothers departed from some private school. Deeply appreciative of every blessing large or small that has come to you, you should be restless in your endeavours to send students to your Alma Mater until no sister shall look out upon an empty bench, until the gymnasium and campus ring with the excited shouts of happy and healthy young girls. ${ }^{50}$

Much could be written about the bonds between the pupils and their teachers. In the course of the school's history, several hundred sisters lived at Loretto Niagara. In 19378 , the year of the fire, for example, the school was staffed by 31 teaching sisters and 7 house sisters, with 5 sisters who taught in the separate schools also in residence. The school housed 61 boarders and 145 Day pupils. The school staged many public events including concerts and dramatic presentations (such as the 1947 production of The Maid of Orleans) - some written by the Sisters themselves (such as the Loretto-Niagara Centenary Pageant "Hours of Destiny"). The latter was described in a handwritten note as "A Masterpiece oops - Mistresspiece" by Mother Frederica Boyle, the Superintendent of Schools Toronto). The presentations celebrated Christian virtues - and in many cases, focused on the significant roles that women played. Perhaps it was through their participation in some of these celebrations, especially those celebrating the achievements of Mary Ward, that some of the pupils decided to explore religious life. At least seven former pupils of Loretto Niagara entered the congregation, including Madeleine MacMahon (1894-1990), one of the "mystic nine" graduates of 1911, the school's Golden Jubilee Year. ${ }^{51}$

Mother Mary Constance was born in Elmira New York. She was a pupil of both Loretto Stratford and Loretto Niagara. After her graduation from Loretto Niagara, she attended Elmira College, New York, receiving a Bachelor of Arts. She enetered the community in 1918 and had a career as a teacher and administrator in a number of 
Loretto schools in Canada and the United States, including the principalship of her alma Mater, Loretto Niagara (1933-1939). Mother Mary Constance was elected General Superior of the Congregation in 1955 and led the congregation through some of its most challenging times, including the decision to support the rights of black students to a Catholic education that led to the closure of the two Chicago schools. ${ }^{52}$ She was also at the congregation's helm through the implementation of the reforms of the Second Vatican Council. Her congregational obituary comments:

Sister Mary Constance was gentle but firm .... Always gracious and refined but never aloof, she was noted for her hospitality and charity to others .... A practical woman, she once stated that she did not require people with brilliance of intellect, just common sense. ${ }^{53}$

As evident these examples of the curriculum, the sisters and the surroundings, convent schools are complex organizations, where the gendered nature of education can be explored in the hidden and overt curriculum. This school, located below the rainbow of Niagara is both typical and unique - typical of its genre; unique in its location and the extent to which its physical location shaped it history, its development and its psyche.

\section{Directions for Future Research}

Loretto Niagara ceased to be a boarding school in 1969. By 1975, it became a coeducational high school and outgrew the resources of the community and the physical plant. On 29 October 1981, the General Superior wrote to "Parents, Friends and Alumni of Loretto Niagara Falls" announcing the closure of Loretto Academy. She explained:

A trend felt in North American Congregations has affected Loretto also. Many of our Sisters have reached retirement age; some Sisters have left religious life; others have altered their educational ministry; many younger women enter with specialized certification in related areas of service but not teaching. These factors, along with overcrowding and inadequate facilities for the size of our school and increasing financial difficulties have led us to this decision. ${ }^{54}$

From 1982 to 2005, the Loretto Christian Life Centre operated out of the building, offering retreats, recreational programs and a residential Spiritual Centre Outdoor Education Program (SCOEP) for graduating elementary school students from the Niagara Peninsula. On 28 September, 2005, a ceremony was held to mark the community leaving Loretto Niagara. Sister Helen Cameron reflected:

Teresa [Dease] was always a woman of faith; so are we. We all know what a privilege and a gift it has been to have a convent overlooking Niagara, to work there, to pray there, to enjoy its beauty. Are we now invited to experience a different 
kind of gift, a more painful one - that of moving forward to another form of mission, a work that is still not clear? Are we meant to be like the waters of the Niagara River, always on the move? ${ }^{35}$

The history of Loretto Niagara is a history of movement - and one which reflects the changing educational norms. The curriculum delivered at Loretto Niagara - the academics, the arts, sport and leisure studies - was shaped by the natural environment, shaped the gendered environment and gave shape to the school's physical development.

How the school culture was shaped and how the curriculum interacted with both the social and physical environment needs to be further explored. While some scholars have begun to explore this, there is much more that needs to be done. ${ }^{56}$ Loretto Niagara yields an example of a site that integrated the environment within all phases if its history. As well, it was a site where the arts played a key role in linking the school with the larger community. The recognition and assessment of fact that the convent was the site (and in many towns the only site) of music and fine arts education has yet to be fully analyzed in the scholarly literature. Many of the music pupils who came as boarders the convent schools returned to their small towns and contributed to the domestic economy by offering private music lessons in their homes. In other communities throughout Canada, when sisters were sent out 'on mission' frequently a music teacher was sent with them. Her duties were to provide domestic support to the teaching sisters and to finance the endeavours by offering private music lessons. The revenue generated by private music lessons flowed back into the community coffers, enabling them to finance their educational, health care and social service activities. The impact that this had on the breaking down of religious stereotyping would make for an important study. On the other hand, the extent to which participating in denominationally oriented sport and leisure study activities contributed to the maintenance of prejudices also deserve exploration. How schools situated themselves within the physical environment and the extent to which they made use of their surroundings for pedagogical purposes needs to be explored. How valid was the Sisters' claim:

If it is true that close communion with nature, especially with nature in its more beautiful aspects, the to enlarge the mind and ennoble the heart, then we can readily understand the immense advantage that pupils of Loretto derive from their close proximity to the Falls. This, in itself, is an educational factor wich cannot be easily overestimated. ${ }^{56}$

Only more research into the school below the rainbow can establish the validity of this assessment. 


\section{Notes}

1 This paper is part of a course of research on the roles of women religious in the educational history of English-speaking Canada. The author thanks the Archivist and Leadership team of the Institute of the Blessed Virgin Mary (Canadian Province) for access to the archival data utilized here

2 "Loretto Convent, Niagara Falls" in J.B. Dollard. Poems. (Toronto: The Catholic Church Extension Society of Canada, 1910) available: http://www.niagarapoetry.ca/dollard.htm

3 The 1951 first communion class, for example, was composed of 22 girls and 4 boys.

4 ANA. Box 4. "A Synopsis of the History of Loretto Acadamy" by Sister Isidore Sheerin. October 31, 1981.

5 For a more detailed analysis see E.M. Smyth, (1998). "Women Religious and Their Work of History in Canada, 1639-1978: A Starting Point for Analysis.” Historical Studies, 64, 135-150; E.M. Smyth,. (2000). "Preserving Habits: Memory Within Communities of English Canadian Women Religious.” In S. Cook, L. McLean \& K. O’Rourke (Eds.), A Century Stronger-Women's History in Canada 1900-2000. Kingston and Montreal: McGillQueen's Press. 22-26.

6 C. Lacelle. "L'apport social des communautes religieuse catholique presentes au Canada avante 1940." Unpublished manuscript prepared for Parks Canada (Ottawa, 1987).

7 Among the key and recent works on women religious in Canada are G. Anthony, SC, A Vision of Service: Celebrating the Sisters of Charity (Kansas City: Sheed \& Ward: 1997); G. Anthony, SC, Rebel, Reformer, Religious Extraordinaire: The Life of Sister Irene Farmer SC (Calgary: University of Calgary Press, 1977);R. Bruno-Jofré, The Missionary Oblate Sisters: Vision and Mission (Montreal \& Kingston: McGill-Queen's University Press, 2005); J. Cameron, For the People: A History of St. Francis Xavier University (Montreal and Kingston: McGill-Queen's Press, 1996); J. Cameron, 'And Martha Served:' History of the Sisters of St. Martha, Antigonish (Halifax: Nimbus, 2000); T. Corcoran, SC, Mount Saint Vincent University: A Vision Unfolding 1873-1988 (Ladham: University of America Press, 1999); M. Danylewycz, Taking the Veil: An Alternative to Marriage, Motherhood and Spinsterhood in Quebec, 1840-1920 (Toronto: McClelland and Stewart, 1986); M. D'Allaire, Les communautés religieuses et l'assistance sociale à Montréal 1659-1900 (Montreal: Editions du Meridien, 1997); M. Dumont et N. Fahmy-Eid, eds., Les Couventines: L'education des filles au Quebec dans les congregations religieuses enseignantes 1840-1960 (Montreal: Boreal, 1986); J.K. Gresko, Gender and Mission: The Founding Generations of the Sisters of Saint Ann and the Oblates of Mary Immaculate in British Columbia 1858-1914(Unpublished Ph.D. Thesis: University of British Columbia, 1999); D. Juteau et N. Laurin, Un métier et une vocation: Le travail des religieuses au Québec de 1901 à 1971 (Montréal: Les Presses de l'Université de Montréal, 1997); G. Laperriere, Congregations religieuse de la France au Quebec, tome 2 (Quebec: Les Presses de Université Laval, 1996); N. Laurin, D. Juteau et L. Duchesne, À la recherche d'un monde oublié. Les communautés religieuses de femmes au Québec de 1900 à 1970 (Montréal: Le Jour, 1991); M.J. Losier, Amanda Viger: Spiritual Healer to New Brunswick's Leprosy Victims 1845-1906 (Halifax: Nimbus 1999); H. MacDonald, The Sisters of St. Martha and Prince Edward Island Social Institutions, 1916-1982 (Unpublished Ph.D. Thesis: University of New Brunswick, 2000); M.O. McKenna,. SC., CHARITY ALIVE: Sisters of Charity of Saint Vincent de Paul, Halifax 1950-1980 (Lanham, MA: University of America Press, 1998); D. Rink, Spirited Women: A History of Catholic Sisters in British Columbia (Vancouver: Harbour Publishing/Sisters' Association Archdiocese of Vancouver, 2000.); Smyth, "Preserving Habits"; E.M. Smyth, "Professionalization Among the Professed," in E.M. Smyth, A. Prentice, S. Acker and P. Bourne, eds., Challenging Professions: Women and the Professions in English Canada (Toronto: University of Toronto Press, 1999), 234-54; E.M. Smyth, "Writing Teaches Us Our Mysteries: Women Religious Recording and 
Writing History, " in A. Prentice and B. Boutilier, eds., Creating Historical Memory: English Canadian Women and the Work of History (Vancouver: University of British Columbia Press, 1997), 101-128; R. Sullivan, Revolution in the Convent: Women Religious and American Popular Culture, 1950-1971. (Unpublished Ph.D. Thesis: McGill University, 1999). Scholarship on New France is more promising in this area as is the work of American scholars. See Grace Donovan SUCS. "Immigrant Nuns: their Participation in the Process of Americanization" Catholic Historical Review 77 (2) April 1991 194-208; Patricia Byrne "Sisters of St Joseph: The Americanization of a French Tradition" US Catholic Historian 5 (3\&4) Sumer/Fall 1986, 241-72.

8 Archives of the Sisters of St Joseph of Toronto (Hereafter ASSJ). J..P. Medaille (1657). Maxims of the Little Institute. (Translated and Published by the Federation of the Sisters of St Joseph USA. Erie PA: 1975).

9 C. Heilburn. Women's Lives: The View from the Threshold. (Toronto: University of Toronto Press, 1999), 101.

10 Typical of these works are M.J. Daigler, (ed). Through the Window: A History of the Work of Higher Education Among the Sisters of Mercy of the Americas. (Scranton: University of Scranton Press, 2000); A. Harrington and P. Moylan, (eds). Mundelin Voices: The Women's College Experience 1930-1991. (Chicago: Loyola, 2001); C.Coburn and M. Smith. Spirited Lives: How Nuns Shaped Catholic Culture and American Life, 1836-1920 (Chapel Hill : UNC Press, 1999); M.C. Chandler, Supporting the Social Identity of Women Religious: A Case Study of One Apostolic Congregation of Women Religious in the United States. (Unpublished Doctoral Dissertation, Graduate Theological Union, Berkeley, CA, 2001).

11 For a fuller discussion see E.M. Leonard, "Separation of the Sexes: The Development of Gender Roles in Modern Catholicism" in J. Martos and P. Hegy, Equal at the Creation: Sexism, Society and Christian Thought. (Toronto: University of Toronto Press, 1998). 114-2; J.K. McNamara, Sisters in Arms: Catholic Nuns through two millennia. (Cambridge: Harvard, 1996); J. Manning, Is the Pope Catholic: A Woman Confronts her Church. (Toronto: Malcolm Lester, 1999).

12 For a history of the Institute of the Blessed Virgin Mary in Canada see M.Costello, Life and Letters of Mother Teresa Dease (Toronto: 1916); M. Norman, IBVM, "Making a Path By Walking: Loretto Pioneers Facing the Challenges of Catholic Education on the North American Frontier," Historical Studies 65 (1999): 92-106; K. McGovern IBVM, Something More Than Ordinary (Richmond Hill, Ontario: 1989); Mary Aloysius Kerr, IBVM, Dictionary of Biography of the Institute of the Blessed Virgin Mary in North America (Toronto, Ontario: 1984).C. Lei "The Material Culture of the Loretto School for Girls in Hamilton, Ontario, 1865-1971." Historical Studies, 66 (2000), 92-113

13 For a discussion of Power's brief career see M. McGowan Michael Power: The Struggle to Build the Catholic Church on the Canadian Frontier. (Kingston:McGill-Queen's Press, 2005).

14 McGovern, 97.

15 As quoted McGovern, 104.

16 For further discussion see D.L.Nash-Chambers, D.L. "In the Palm of God's Hand? The Irish Catholic Experience in Mid-Nineteenth Century Guelph” Historical Studies, 51(1984), 67-87

17 There are several versions of the legend. The common themes are: human sacrifice/suicide of a beautiful maiden to the Thunder gods; the presence of evil in some form (disease/a snake like creature killing tribes people); the return of the maiden to her tribe or to live as a the maid of the mist in the cave of the gods. Current anthropological evidence suggests that the tribes never did practice human sacrifice and although the name of the Maid of the Mist survives in the names of the boats who take visitors to the brink of the Falls, the legends are no longer part of the interpretations (See: http://www.infoniagara.com/d-attlegend.html; http://www.bodyinmind.com/May17,1999.htm; 
http://www.courses.rochester.edu/foster/ANT226/Archive/Fall98/1.html http://www.yvwiiusdinvnohii.net/articles/maidmist.htm

18 S. Morley . The Quotable Oscar Wilde (Philadelphia, PA: Running Press, 2000) available: http://www.quotesandsayings.com/goscarwilde.htm

19 Institute of the Blessed Virgin Mary, Archives, North America [Hereafter ANA] "Pastoral Letter of His Grace the Archbishop of Toronto on the Catholic Institutions at Niagara Falls. [26 April 1876]. Box 1, 1

20 ANA. "Pastoral Letter", 5.

21 ANA. "Pastoral Letter", 1.

22 ANA. "Pastoral Letter", 1.

23 ANA. "Pastoral Letter", 2.

24 ANA. Chronicle 1847-1876.

25 ANA Loretto Academy (Loretto of the Blessed Sacrament) "Pioneering Community"

26 This is not to say that the schools were universally accepted. The presence of Loretto Toronto stimulated the founding of a number of independent girls' boarding schools administered by other denominations. Toronto's experience mirrored that described in R. Kollar "Foreign and Catholic: a plea to Protestant parents on the dangers of convent education in Victorian England." History of Education Volume 31, Number 4 July 01, 2002, $335-350$.

27 ASSJ."St. Joseph's Convent," "Written for the Catholic Register," (1897), Catholic Register, "Scrapbooks," vol. vii, 25.

28 ANA Constitutions of the Institute of the Blessed Virgin Mary. Toronto: no 1942, p.1. [Hereafter Constituion 1942]

29 Constitution, 84.

30 AHA "Loretto Academy, Niagara Falls" nd. Tuition for room and board was $\$ 100$ per term with additional subjects offered at prices ranging from $\$ 10$ for Class Singing to $\$ 30$ for piano.

31 AHA "Loretto Academy, Niagara Falls" nd

32 Loretto Beautiful.

33 ANA. "Ave Maria Loretto File." As the Loretto network of schools expanded, more verses were added to the song, each reflecting the local character. A handwritten note explains "Mother St Winifred taught this to all the High School Students and it was sung with GUSTO and LOVE [emphasis in original] at event occasion that represented itself."

\section{Loretto Beautiful}

35 Loretto Beautiful

36 Loretto Beautiful

37 Loretto Beautiful

38 ANA. Application. Box 3. For the resident pupils, the cost of $\$ 400$ per term (2 terms per year) with additional costs for Piano, Violin, Voice ( $\$ 130$ for 2 lessons weekly).

39 As Marjorie Theobald argues, this curriculum should be viewed as anything but 'mere". M. Theobald “'Mere Accomplishments'? Melbourne Early Ladies' Schools Reconsidered." History of Education Review 13 (1884), 15-28.

40 ANA. Box 3. Report Card, 1897.

41 For a further discussion see E. Smyth The Lessons of Religion and Science. (Unpublished doctoral dissertation. University of Toronto, 1990); C. Lei “ 'The Science Ball': Poetry as Historical Evidence" Historical Studies, 70 (2004), 9-28; C. Lei, Academic Excellence, Devotion to the Church and the Virtues of Womanhood: Loretto Hamilton, 1865-1970.

(Unpublished doctoral dissertation, Univerity of Toronto,2003).

42 ANA Application

43 ANA. Box 3, 1938.. Loretto Academy Niagara Falls [1938]

44 ANA. Box 3: Timetable.

45 ANA. Customs [1960], 112. 
46 ANA. Customs [1960], 114.

47 ANA. Box 3. Loretto Academy Niagara Falls [1938], np.

48 ANA. Box 3. Loretto Academy Niagara Falls [1938], np

49 ANA. Box 3. Loretto Academy Niagara Falls [1938], np

50 ANA. Box 1 "Sermon preached by Very Rev J.M. Noonan, C.M, President of Niagara University. Sunday, June 26, 1936.

51 The number of young women entering the congregation from Loretto Niagara is parallel to the findings for St Joseph's Academy Toronto. Similarly, those who did enter went on to assume positions of leadership within the congregation. See Smyth "The Lessons of Religion and Science"

52 For further analysis, see S.M. Hoy, "No Color Line at Loretto Academy: Catholic Sisters and African Americans on Chicago's East Side" Journal of Women's History. Volume 14, Number 1, Spring 2002, pp. 8-33

53 ANA. Box 1. "List of Teachers"

54 ANA Box 4 Sister Frederica Boyle. October 29, 1981.

55 Helen Cameron, 28 September 2005.

Available:http://www.ivbm.org/content/view/98/139/

56 See for example the work of Lei "The Material Culture", N. Baumgarten (1994)

"Education and Democracy in Frontier St. Louis: The Society of the Sacred Heart." History of Education Quarterly, Vol. 34, No. 2 (Summer), pp. 171-192, R. Gilchrist, Gender and Material Culture: The Archaeology of Religious Women (London: Routledge, 1994); V. Bennett, Sacred Space and Structural Style: The Embodiment of Socio-Religious Ideology (Ottawa: University of Ottawa Press, 1997; C. Trimingham Jack, C. (1998) 'A moulding haven? Competing educational discourses in an Australian preparatory school of the Society of the Sacred Heart, 1944-65, 